\title{
FORMATION AND DEVELOPMENT OF AXIOLINGUISTICS
}

\author{
Komilova Gavharoy Ruzimovna ${ }^{1}$ \\ ${ }^{1}$ Lecturer (independent researcher) Tashkent State University of Uzbek Language and Literature named \\ after Alisher Navoi, Faculty of Uzbek Philology, Department of Uzbek Linguistics. \\ E-mail: r_gavharoy@mail.ru \\ Z.Xolmanova ${ }^{2}$ \\ ${ }^{2}$ Prof. Scientific adviser, Doctor of Philosophy, \\ Tashkent, Uzbekistan
}

\begin{abstract}
Modern linguistic research focuses on the practical problems of science, mainly on the person himself, i.e. his emotional-mental sphere, ethical and aesthetic views in man, the value system, the processes of understanding and perceiving the world. Mankind's spiritual experiences, attitudes, and values are reflected in his language. In this sense, axiolingual research shows the relevance of the topic. This article analyzes a number of studies on the formation and development of axiolinguistics that are currently evolving.

Keywords: axiology, axiolinguistic value, evaluation, subjective evaluation, language, axiological approach, axiological vocabulary, paremia, proverb, proverb,.

\section{INTRODUCTION}

Modern linguistic research focuses on the practical problems of science, mainly on the person himself, that is, his emotional-mental sphere, ethical and aesthetic views in man, the value system, the processes of understanding and perceiving the world. Mankind's spiritual experiences, attitudes, and values are reflected in his language. In this context, axiolinguistic research demonstrates the relevance of the topic.

It is well known that values should be seen not only as an integral part of culture and the spiritual dominance of the individual, but also as an object of perception, a way of expressing a person's need for evaluation and evaluation. Therefore, identifying and describing assessment tools is the most important goal of axiological linguistics. Indeed, language includes the means of expressing values as a means of evaluating the world and man $[4,732]$.
\end{abstract}

\section{THE PURPOSE AND OBJECTIVES OF THE WORK}

In recent years, new directions in axiology have emerged in linguistics. Initially, A.A. Scholars such as Ivin, N.D. Arutyunova, M.Wolf, S.G.Pavlov, F.Serebryannikova have shown axiological linguistics as a separate direction in their research. SG Pavlov considers the object of linguistic axiology in a complex way as "language - consciousness - society - culture - man." As a subject, it takes linguistic means of expressing and shaping values [14,58-59].

The first ideas about axiolinguistics belonged to Aristotle, who worked within 3 concepts: goodness, happiness, pleasure. In this, good is evil, evil; happiness failure; pleasure has been studied as the opposite of unhappiness.

The first interests in the spiritual nature of man, his inner world, began in philosophy in the XVII century. One such study was conducted by T. Gobbs, who defined the concepts of good and evil through feelings such as dream, love, joy, disgust, hatred, sorrow [1, 17].

"Simple philosophy," writes N.D. Arutyunova is reflected in the system of experience and works of art, emotions and values as a result of the interaction of a number of factors, such as national traditions and folklore, religion and ideology, life "[1,3].

The task of developing a general theory of the axiom in modern linguistics is associated with the emergence of many new axiologically oriented disciplines in linguistics, such as ethnolinguistics, ecolinguistics, critical discourse analysis, and social analysis.

Thus, while linguistic axiology is shaped by the paradigm of language-society-culture-world hypothesis, this paradigm in turn suggests the study of the essential meanings of social being, which is the regulator of activity and the meaning of life.

\section{MAIN PART}

At the same time, the owner of language, through language, purposefully and epistemically expresses his consciousness, memory, will, emotional and mental state as the creator of the world. This process involves self-awareness, mastery of the conceptual world on the topic, and modeling of the world in speech [17, 6 -11].

Values, as ideals and priorities of human activity, reflect the spiritual and material world of an individual. 
Linguistic axiology considers language to be the most important source of information about values. And at the same time, it is evolving as a new linguistic field. Bejis M. Heidegger did not say in vain: "Language is the house of the soul". Language, as the house of the soul, first develops normative concepts. Language also has many functions, and these functions work according to their own rules.

Anthropocentric approaches and axiolinguistic research cover not only how a person is described in a language, but also what a person believes, as well as everything that is valuable to him or her or to society.

Arutyunova [1], G.G Slishkin [18], B.I. Karasik [11], LK Bayramova [3] and other researches serve as a theoretical basis for the development of axiolinguistics.

While in the classical period the line of development of axiology was related to the concepts of human behavior, good and evil, duty and obligation, desire and pleasure, in later studies these concepts were applied through conceptual and linguistic analysis of relevant words. The aim was to determine the conditions of use and the communicative purposes of those speech actions that were part of them.

In modern linguistics, research in this area is mainly comparative. Melnichuk also noted that as a comparative branch of axiolinguistics, it develops gradually as a system [13, 8-10].

Evaluating values, Arutyunov, one of the founders of axiolinguistics, wrote: "The concept of value serves as a coordinator, stimulator (guide) and didactic and regulatory between man and objects in the world" $[1, \mathrm{~A}, 60]$.

Axiolinguistic research is the study of the reflection of values in phraseology and paremiology by analyzing the concepts of evaluation, evaluation expressed in linguistic units. As a result, general and specific aspects in different languages were identified. For example, R.D. Yunusova "Axiology of phraseological units with the meaning of hospitality / kunakchyllik 'in Russian and Tatar languages" in the dissertation of the candidate, the concept of hospitality in two unrelated languages was considered in the context of phraseology as a moral value. His dissertation identifies the priorities of morality in the phraseological units of hospitality in the Russian and Tatar languages, their national and cultural values. In the end, the concept of hospitality comes in many forms. In Russian and Tatar phraseological units, the occurrence of partially equivalent, phraseological analogues and lacunar units has been noted [20,6].

Another area of research in this area is related to the theoretical development of the axiological paradigm, which has been reflected in a number of studies [2,3].

Axiolinguistics is also rich in scientific research on the analysis of cultural strata (cultural codes) in proverbs, using proverbs as ethical guidelines for the study of values.

Universal cultural codes are always defined at the national level and blended with the specific culture of the people.

The purpose of this study is to study the axiological component of the value in proverbs and to determine the axiological information in the material under study.

The proverb reflects the worldview from ancient times, the macro and microcosm of man and his spiritual values.

Normative situations are expressed in language, mainly in proverbs. Because the articles show people's advice and appreciation. But examples of folklore do not always provide a complete picture of the values of society in modern culture.

In English, one can see the disappearance of proverbs in the process of communication, and several proverbs are used as an element of instruction [10,23].

The values and moral values in proverbs have also been studied by P. Grace. proverbs.

Many subsequent studies have shown that values are expressed in a systematic way in the body of

Karasik analyzes Russian and English proverbs, their value - value, morality. The idea of equality and inequality is one of the highest norms. An analysis of proverbs shows that there are many proverbs written by men that express the low status of women: A chicken is not a bird, a woman is not a man "," A woman from a cart is easier for a mare "," Consult a woman and do the opposite "

A similar negative assessment was applied to the language in relation to other nationalities: to go Dutch — go to a restaurant on terms where everyone pays for himself ("in Dutch"), a French disease — "French (venereal) disease", to take a French leave — to leave "in French", without saying goodbye, we note that the French, and then the Russians, use the reverse expression to leave in English with the same meaning) [10, 27].

The research in the laboratory of "Axiological Linguistics" under the direction of Karasik is also noteworthy. In them, the analysis of normative situations and moral norms between unrelated languages is also practical in international relations [10, 2004].

Also noteworthy is the work on the concept of happiness in the formation of axioinguistics as a science.

Written by SG Vorkachev "The concept of happiness in the Russian language consciousness: the experience of linguoculturological analysis" [6] monographs, as well as articles based on materials in Croatian, Russian, English, and Tatar, provide an analysis of the assessment of happiness [3: 471-473; 36-40].

Linguistic material reflects what exists in society and philosophically meaningful views, and the following rules about happiness and a happy person are given: A person's happiness does not depend on him: it is given to him because of a favorable combination of destiny or situation. Looking at happiness as an 
independent phenomenon is expressed, for example, in such proverbs and sayings: Russian Happiness is a free bird: wherever she wanted, she sat down there; English The lines

have fallen to me in pleasant places - a happy lot fell to my lot; tat.

Behet chakyrsats da kilmi - behetsezlek kusats da kitmi. [2.28]. Or, conversely, there are places where happiness is considered to belong to the individual, and there is a general and national expression of these in these languages.

Linguoaxiology, in conjunction with the paremiological fund, allows the study of literary texts and other texts, dialogues, conversations as an object of study to identify values of different ages and genders, professional and class values, or individual values. For the first time, one of the views on texts as an expression of aesthetic values appears in Galperin's works. [7, 2].

In recent years, axiolingual research has shed light on questions about the national linguistic consciousness and its model. For example, A.V. Golovanova [9] explored the similarities and differences between the value systems of the two peoples through the concepts of indifference and stupidity expressed in Polish and Russian.

Axiolinguistic researches in Slavic languages can also be exemplified by the scientific researches of GD Gachayev, SG Terminasova, LG Babenko, EB Babayev, EV Ivanova. For example, Terminasova comparatively studies the meanings of values in Russian and English and finds that the following values prevail in the formation of sentences in English: honesty, prudence, diligence, professionalism, responsibility, frugality, thrift, selfishness, personal freedom, conservatism, material prosperity, zakrыtost semeynoy jizni. In Russian, the following values are predominant: experience, courtesy, corporate, fairness, hospitality [19, $166]$.

In addition, the axiological modality in Uzbek linguistics is currently being studied by J. Yakubov, G. Kambarov, S. Boymirzayeva [5], Z. Pardayev [13]. In particular, the main scientific researches and articles of Z. Pardayev published in recent years are aimed at studying the communicative-pragmatic possibilities of axiological assessment. Also, M. Rakhmatova's dissertation "Linguistic features of the concept of" beauty "in the English, Uzbek and Tajik national culture" [16] PhD in philological sciences The specific features are described on the basis of comparative analysis.

The main component of human speech activity is linguistic consciousness. VV Krasnix divides mental information into two opposing types: knowledge and imagination. When knowledge is interpreted as relatively stable, objective and collective units of information, the imagination acquires a changeable, subjective, individual essence, representing the individual imagination, image and concept, as well as the connotations and values associated with them [12,41-45].

In a value-based approach, a linguistic personality consists of the specific ethical and beneficial moral norms of a particular nation at a particular time. This norm is enshrined in the code of ethics of the people and reflects the worldview and history of the people, along with language and history. The code of ethics of a people is expressed in language, for example, in the general opinions of the people or in similar texts, in cultural texts, in the ethical rules of language owners, in the communicative strategy of behavior, in words that express value. Common values, like national values, are divided into specific group and individual values. Therefore, a linguistic personality is defined in terms of its relation to dominant values in a value or spiritualmoral aspect $[11,19]$.

In general, values are the recognition that people's feelings take precedence over everything else, and what you aspire to, think, respect, or vice versa.

In this sense, values are the means by which generalized goals and their achievement, achievements, fundamental norms, or ideals play a role. The important point is that the existence of an object as a real value is understood not only in intellectual rational action, but also in emotion, in experience.

The purpose of value is regulation [10,203]. Values emphasize the relationship between the world and man, what is in the world, including what is important to humanity.

Moreover, this significance has a moral character because it expresses an attitude towards objective truth based on good and evil. The relationship between value and purpose is that "genetically, values are abstracted from purpose. Goal setting is done according to values. Values regulate behavior, general intentions, predetermination of action " $[10,202]$.

In this regard, values are seen as a deeply motivating basis for beliefs and behaviors. Values are related to man and society, apart from them, there are no values outside the relationship to the person, the objects themselves are not included in the classification of values, values are formed by the person in his production activities.

O what does axioinguistics give to science?

Every nation has its own culture, language, traditions, customs, rituals and moral values. Linguoaxiological analysis allows the study of the national linguistic consciousness, the model structure of the linguistic personality, because language as a cultural phenomenon forms a system of direct values, reflects the system of evaluation and eternal values in a particular society.

Culture is also constantly evolving with thinking, shaping the language owner as an individual (belonging to a particular society, linked to and developed by a system of values).

\section{CONCLUSION}

Volume 3, Issue IX, September 2020 | 130 
In short, axiological lexicon, while expressing important concepts in the life of a people, reflects the traditions, perceptions of existence, and moral norms that have risen to the level of value for a particular people. Proverbs, on the other hand, are the main field of reflection of axiological lexicon, as they cover all aspects of people's lives. As the paremologist Anikin put it, "What is not in the experience of the people is not in the proverbs." National cultural identity is reflected in folklore.

\section{REFERENCES}

[1] Arutyunova N.D. Types of language values: Assessment. Event. Fact / - M .: Nauka, 1988 .-- 341 p.

[2] Bagautdinova G.A. Man in phraseology: anthropocentric aspect / - Kazan: Kazan Publishing House. University, 2006 .-- 132 p. (8.25 pp.) .. Bagautdinova G.A. Axiological linguistics: linguistic value of linguistic units and values expressed by linguistic units / G.A. Bagautdinova // III International Baudouin readings: I.A. Baudouin de Courtenay and modern problems of theoretical and applied linguistics (Kazan, May 23-25, 2006. ): works and materials: in 2 volumes / Kazan. state un-t; under total. ed. K.R.Galiullina, G.A.Nikolaeva.-Kazan: Kazan Publishing House. University, .- Kazan: Kazan Publishing House. un-ta, 2006. - T. 2. - S. 132-135.

[3] Bagautdinova G.A., Bayramova L.K. Axiological phraseology about happiness // Scientific notes of Kazan State University. Volume 148, book. 2. Humanities - 2006.

[4] Yunusova R.Zh .. Axiology of phraseological units with the meaning of 'hospitality / kunakchyllyk' in Russian and Tatar languages. Abstract of dissertation for the degree of candidate of philological sciences. Kazan - 2009.

[5] Ter-Minasova S.G. Language and intercultural communication / - M .: Slovo, 2000 --- 624 p.

[6] Slyshkin G.G. Linguocultural value vs philosophical value // Izv. Volgogr. state ped. un-that. Ser. "Socio-economic sciences and art". - 2004. - No. 2. - P. 46-50. Slyshkin G.G. Modern Russian anecdote: functions and value dominants // Axiological linguistics: game and comic in communication: Sat. scientific. tr. - Volgograd: Change, 2003.

[7] Serebryannikova. E.F. Linguistics and axiology: ethnosemiometry of value meanings: a collective monograph /. - M .: TEZAURUS, 2011 .-- $352 \mathrm{p}$.

[8] S.Y.Temurov: Theoretical bases of formation of professional competence in future mathematics teachers. Tashkent: Science and Technology-2014 p.44

[9] N.Muslimov, M.Usmonoboeva, D.Sayfurov, A.Turaev: Fundamentals of pedagogical competence and creativity. Tashkent-2015, p.25

[10] Rakhmatova M. Linguistic features of the concept of "beauty" in English, Uzbek and Tajik national culture. Doctor of Philosophy (PhD) in Philology. - Buxoro, 2019. 51 p.

[11] Pardaev Z. On the concept of assessment in linguistics and its study // Uzbek linguistics in the XXI century (Proceedings of the scientific-theoretical conference dedicated to the 70th anniversary of Professor Tora Nafasov) .- Karshi, 2008. 214-220-p; Pardaev Z. Assessment category and its interdisciplinary relationship // R. Issues of Kungurov's scientific heritage and Uzbek linguistics.- Samarkand, 2008. pp. 78-81.

[12] Pavlov S.G. Lingvoaxiological model of man: scientific and methodological aspect / Bulletin of the Minsk University. - Mn., 2013. - No. 2. - P. 56-68.

[13] Melnichuk V.A. Axiological dynamics of Russian vocabulary (late 18th - early 21 st century) diss. Cand. philol. Sciences: St. Petersburg 2017.216 p.

[14] Krasnykh V.V. Ethnopsycholinguistics and cultural linguistics: A course of lectures. Moscow: Gnosis $2002.284 \mathrm{p}$.

[15] Karasik V.I. Language circle: personality, concepts, discourse. - Volgograd, 2002 .-- C 331.

[16] Ivin A.A. Modern axiology: some topical problems / Philosophical journal. - 2010. - No. 1 (4). S. 66-78.

[17] Golovanova A.V. Values and assessments in linguistic reflection: Dis. ... Candidate of Philological Sciences. Perm, 2002.200 s.

[18] Gibatova G.F. Axiology in language. OSU Bulletin No. 2 (121) / February`2011.

[19] Galperin I.R.Text as an object of linguistic research / - M .: Nauka, 1981 --- 144 p.

[20] Vorkachev S.G. Lumen naturale: the axiology of intelligence in language: monograph /.Krasnodar: Ed. FGBOUVPO "KubGTU", 2016. - 296s.

[21] Boymirzaeva S. Categories that form the communicative-pragmatic content of the text in the Uzbek language. Filol. fan. doc. diss. avtoref.- Toshkent, 2010.- 49 p. 